\title{
The history curriculum and its personal connection to students from minority ethnic backgrounds
}

Article

Accepted Version

Harris, R. and Reynolds, R. (2014) The history curriculum and its personal connection to students from minority ethnic backgrounds. Journal of Curriculum Studies, 46 (4). pp. 464486. ISSN 1366-5839 doi:

https://doi.org/10.1080/00220272.2014.881925 Available at https://centaur.reading.ac.uk/37661/

It is advisable to refer to the publisher's version if you intend to cite from the work. See Guidance on citing.

Published version at: http://dx.doi.org/10.1080/00220272.2014.881925

To link to this article DOI: http://dx.doi.org/10.1080/00220272.2014.881925

Publisher: Taylor \& Francis

All outputs in CentAUR are protected by Intellectual Property Rights law, including copyright law. Copyright and IPR is retained by the creators or other copyright holders. Terms and conditions for use of this material are defined in the End User Agreement.

www.reading.ac.uk/centaur 
Central Archive at the University of Reading

Reading's research outputs online 
The history curriculum and its personal connection to students from minority ethnic backgrounds

Richard Harris and Rosemary Reynolds

Richard Harris is a lecturer in history education at the Institute of Education, University of Reading, 4 Redlands Road, Reading, RG1 5EX, UK; e-mail: r.j.harris@reading.ac.uk. His interests are in perceptions of the history curriculum, the place of diversity within the history curriculum, and the public and political discourse around history education.

Rosemary Reynolds is a doctoral research student at the Institute of Education, University of Reading. Her interests are history and sociology and in particular minority ethnic groups studying in the UK. Her thesis, a work in progress, explores Chinese A-level students in FE colleges; their experiences, expectations and decision-making. 
The history curriculum and its personal connection to students from minority ethnic backgrounds

Whereas history is seen by some as crucial in developing a sense of identity and fostering social cohesion, it is however, often based around narrowly nationalistic views of the past, and yet little is known about how students relate to the past they are taught. Thus, this paper focuses on the history curriculum and the ways in which students aged 12-14, from different ethnic backgrounds, relate to it. Moreover, the small-scale study which enabled this paper, focused, in particular, on whether students enjoyed and valued history and whether they felt any sense of personal connection to the topics studied. Drawing on survey data collected from 102 students and focus group discussions with 42 students, from two high schools, the findings indicate that although many students enjoy history, they fail to fully understand its value. Additionally most students, especially those from minority ethnic backgrounds, feel a lack of personal connection to the past, as they do not see themselves in the history they are taught.

Key words: history curriculum; minority ethnic students; identity; connection

\section{Introduction}

This paper examines the way high school students in two English schools felt about the history curriculum, and whether they sensed any personal 
connection to what they were taught. Moreover, it also explores the extent to which the history curriculum developed any sense of personal and/or collective identity. The focus on students' understanding of history is important in light of the differences between professional and public discourses (Harris 2013, Osler 2009); the professional discourse of history educators often focuses on developing students' understanding of history as a discipline, whereas the public discourse often focuses on the unifying capacity of history to foster a sense of national identity. Examining whether these discourses shape how young people understand history is an area that deserves further exploration. Before examining these issues, this paper will outline the debates about why history should be taught, as part of a general context, with a particular focus on the question of identity formation. Thereafter a literature review will explore the issue of content selection in the curriculum and the impact of this on students. This is followed by an outline of the research approach and the key findings and discussion.

Debates about the nature and purpose of school history have sparked, and continue to spark, extensive and, at times, impassioned argument. At the heart of the debate is a disagreement about what it means to think historically. For some, historical thinking is based upon a detailed mastery of the historical record (for example Hirsch 1987), while for others, it is about understanding that history is a construct and the way in which the past is put together (for example Lee 1992). In recent years more attention has been paid to the notion of developing young people's historical 
consciousness (see Seixas 2004). Put simply, historical consciousness is the way in which people make connections between the past and the present, which consequently affects what they believe is possible in the future. According to Ahonen 2005: 699) it is 'an orientation ... based on the human aptitude to think back and forth in time ... historical consciousness means an interaction between making sense of the past and constructing expectations for the future'. Such debates are notconfined to a particular place, for as Taylor and Guyver (2011) show, arguments about history occur across the globe. In many ways this is unsurprising, as history's power to shape identity, collectively and individually, has been seen as one of the major reasons for its study (Barton and Levstik 2004, Marwick 1989). Barton and Levstik (2004) argue that 'identification' is a key 'stance' as a rationale for studying history; the need to identify with the past, be it at a personal, family or national level 'is a popular one in modern Western thought' (Barton and Levstik 2004: 46), but the emphasis in high schools is often on identifying with a progressive national story. This fits with Seixas' $(2000,2007)$ notion of 'collective memory' where the intention is to teach the 'best' story of what happened in the past. The advantage of such a model is that a focus on a single version of the past can provide a sense of collective identity and social cohesion. The danger is that it becomes history as dogma, 'a catechism to be memorized' (Seixas 2000, 23), and that it often takes as its central focus a narrow, celebratory story of the development of the nation state, which then begs questions of what is the 'best' story, and who decides. There are other concerns with such an 
approach. Green et al. (2003: 455) argue 'it can be harder for education systems to induce social solidarity in the old ways - through promoting national identity and socialisation into relatively uniform sets [of] values and behavioural norms' due to the increasing pluralistic nature of society and erosion of the nation state and social institutions such as family and religion. Moreover, identity is a complex notion. It is broadly acknowledged that people hold multiple identities and that identity is a social construct, but how a particular sense of identity is constructed is less clear, drawing as it does on a range of variables. Barton and Levstik (2004: 64) argue that a focus on a national identity is not a problem as long as this is based 'around historical examples of the key elements of our democracy - pluralism and participation'. However, for Seixas (2000) such an approach runs the risk of presenting knowledge as authoritative and fixed, rather than subject to debate and questions of validity.

To avoid such concerns, Seixas $(2000,2007)$ offers two alternative models of history education, based on a disciplinary approach and a postmodern approach. The disciplinary approach has a strong emphasis on understanding how the past is constructed, and how we come to make claims about the past; there is a focus on working with evidence and developing critical thinking. The postmodern approach requires an understanding of the construction of competing interpretive positions and the contexts in which they are created, for instance, showing an appreciation that interpretations of the past are a product of a particular time and place. 
To an extent these disciplinary and postmodern approaches overlap with Barton and Levstik's (2004) description of another position, which they call the 'analytical stance'. This stance stresses the importance of working with evidence to see how the past is constructed, but also emphasises the importance of using the past to understand the present and helping students appreciate the general lessons of the past, which may influence future actions. These insights, according to Barton and Levstik (2004) should ultimately support participation in democratic society by allowing students to learn from examples in the past. Barton and Levstik (2004) suggest a further two possible 'stances' as rationale for the study of history. The 'moral response' stance requires remembrance, the examination of issues of fairness and justice, and to learn about heroic actions. They also argue there is a need to acquire and pass on information about the past, which they refer to as the 'exhibition' stance. While they admit to some misgivings about this particular rationale, they feel '[p]roviding information [so] that other people ... make judgements, understand humanity, and deliberate about the common good is indispensable for democracy’ (Barton and Levstik 2004: 124).

Within the UK, the dominant trend in school history, as expressed in various iterations of the National Curriculum documentation (for example QCA 2007), has been a combination of the disciplinary and postmodern approaches (McCrum 2013), and is a model to which the authors of this paper subscribe. Although the disciplinary and postmodern approaches stress understanding the process by which the past is constructed, this 
does not mean that debates about the substantive content of the past should be ignored; what content is chosen is incredibly important, and decisions about what to omit are just as important as decisions about what to include in a history curriculum.

Interestingly in the UK, the discourse amongst history educationalists has focused very much on these disciplinary and postmodern perspectives, whilst the public and political discourse around history education in the UK has focused more on a 'collective memory' approach, emphasising what is good about Britain, its history and its contribution to the world (Harris 2013). In the UK politicians have tended to be wary of directly interfering in the construction of a history curriculum, preferring instead to influence debate through public pronouncements. Politicians of different persuasions have called for an emphasis on 'our island story' (Gove $2010^{1}$ ), focusing on 'a golden thread which runs through British history - that runs from that long ago day in Runnymede in 1215; on to the Bill of Rights in 1689 where Britain became the first country to successfully assert the power of Parliament over the King' (Brown, 2006²). Such a narrative tends to focus on a narrow aspect of the past, often a particular political story or one of progress, and potentially presents a single, unifying story of events. The danger of using history as a means of inculcating a sense of social cohesion is that it can result in calls for a simplistic version of the past, which in turn can present an exclusive view of the past; rather than acting as a potential unifying focus such history can serve to alienate some individuals and groups. This notion is supported 
by identity theory. Tajfel and Turner's (1979) theory about social identity, for example, would suggest that the way students self-identify and relate to the past could create in- and out-groups, depending on whether students feel the history that is taught includes them.

Yet comparatively little is known about the impact particular content taught in schools, and their associated narratives, have on young people and their understanding of themselves and the society within which they live. This is important because society is inherently diverse, and there is a danger that simple assumptions about history and what should be studied, and what it will achieve are often untested and unquestioned.

It was against this background, combined with particular public discourse about history in England, which has increasingly focused on a narrow celebratory national story, and a lack of knowledge about what is taught and its impact, that this study was conceived.

\section{Literature review}

There are many studies that question the value of adopting a narrow nationalistic history curriculum. Hansen (2012) highlights the danger of promoting jingoistic attitudes towards the nation state, and Berger (2012) argues that much history transcends the nation state, and so a focus on national history is inadequate. In addition, Grever (2012) highlights the problems that indigenous students face in trying to understand the 
perspective of students from other cultures if there is an over-emphasis on national history. Barton (2012: 103) argues that history is a resource for identity development and students take what they want from it, therefore it is sensible that 'educators should seek to expand rather than constrict the range of identity resources available to students'.

Despite these calls for a broader basis to the history taught in schools, there is still a strong emphasis in public discourse that focuses on teaching a national, often political, story (Harris 2013). Yet there is a gap in our knowledge regarding what is taught in schools and the interaction between school history and students' sense of self. Despite the existence of a National Curriculum for history in England and Ofsted, which inspects school provision across England, little is known about what specifically is taught in schools, and therefore what impact this has on young people who are required to study the subject. This lack of insight is particularly concerning because history is seen to be a subject that contributes to young people's developing sense of identity and it is presumed that this would be influenced by what children actually study and the issues with which they are asked to engage.

Similar claims could be made of places other than England. Few studies have focused on what children are taught in history, whether this history is essentially political, and how children perceive this or make sense of the past they engage with in schools. In general the studies that have been carried out are small-scale. One of the largest studies is an in-depth American study by Epstein (2009) involving 100 students in one school. 
This study looked at history teaching and specifically how pupils from different ethnic backgrounds responded to the curriculum content. The findings indicate a stark racial divide between 'white' and 'black' students in their response to the history curriculum. 'White' students felt comfortable with the content of the curriculum as it reflected a narrative of progress which fitted into their own received histories from home, the media and other sources; it served to reinforce their perceived sense of themselves and the society within which they lived. In contrast, 'black' students felt alienated by the curriculum as it presented a narrative which did not fit into their experiences and received histories within their family and community; for them history was a story of struggle and inequality, which in many cases persisted into the present. This sense that the specific content of a curriculum can alienate groups has been shown in other studies (for example, Nieto 2004) and it has been argued that the curriculum presents powerful messages to young people:

Knowledge taught in schools is a form of cultural capital and is a social construction that reflects the values, perspectives, and experiences of the dominant ethnic group. It systematically ignores or diminishes the validity and significance of the life experiences and contributions of ethnic and cultural groups that historically have been vanquished, marginalized, and silenced. (Gay 2004: 41) 
There have been few comparable studies in the UK that look at the impact of the history curriculum on how young people relate to the content they are taught, and where these have happened they tend to be small scale. One such study was carried out by Traille (2006), and although this research is based upon a small sample, it does provide a valuable in-depth perception of history from pupils of African-Caribbean descent. In particular Traille looked at how pupils responded to the history they were taught and found that topics such as 'Black Peoples of the Americas' (which were seen by teachers as a means of providing a more inclusive curriculum) had an alienating impact on students:

the resulting hurt, anger, bewilderment and feelings of temporary exclusion could impact adversely on their learning experience. (Traille 2006: 169) A focus on enslavement of Africans and their subsequent poor treatment as slaves portrayed black people as victims and generated negative emotions for those African-Caribbean students. Even those aspects of the topic considered positive by teachers, such as the role of the Civil Rights Movement in the United States in its campaign for equality, seem to have little direct relevance to pupils living in the UK. The pupils included in the study were willing to learn about 'British' history but wanted to see a curriculum "that was inclusive of the contributions of other collective groups' (Traille 2006: 160). Hawkey and Prior (2011) also conducted a small-scale study involving 15 students, mostly from minority ethnic backgrounds, in two schools. They highlight a dissonance felt by some minority ethnic students between the types of history young people are 
exposed to at home and those they encounter in the classroom. They conclude that some students from minority ethnic backgrounds do have different views towards the history they are taught, and there were indications in some cases that school history did not fit comfortably with the history that they had learnt elsewhere.

This suggests that in a number of cases there is a disconnection between the history taught in schools and young people from minority ethnic backgrounds. This is hinted at in the DfES (2006) publication Ethnicity and Education, which shows that history is one of the least popular subjects on the curriculum amongst a range of minority ethnic groups, most notably children of Indian, Pakistani and Black African origin. Further evidence from entry figures for public examinations shows a difference in uptake by ethnic background. For example in 2009/10, 30.9\% of all white students chose to study history at $\mathrm{GCSE}^{3}$ in England, compared to $24.9 \%$ of black students and in terms of results $20.8 \%$ of white students were awarded a grade between $A^{*}$ and $C$, compared to $15 \%$ of black students. In the same year $11.6 \%$ of white students chose to study history at Advanced level ${ }^{4}$, compared to $6.5 \%$ of black students (Gibb 2011).

In neither case is there any explanation for the discrepancy in these figures. It may well be that history is not valued as a subject by certain ethnic groups, for whom subjects such as maths and science may be seen as providing stronger career opportunities. However, there is evidence that in some cases it is about the nature and/or content of what is taught, that students from minority backgrounds find disengaging. This issue is 
suggested in a study by Grever, Haydn and Ribbens (2006). In their study they surveyed over 400 pupils aged 15-18 in the Netherlands and England, which specifically included a mixture of indigenous and minority ethnic backgrounds. They found striking differences in the history these groups wanted to study. Students were asked to prioritise a list of different kinds of history; for example national history, European history, world history, family history. While indigenous pupils favoured national history, pupils from minority ethnic backgrounds were more likely to favour history of 'my religion' and ‘where I was born'.

Grever et al. (2006: 7-8) also found that:

Fewer than $50 \%$ of the respondents agreed with the statement that a ‘common history creates mutual bonds', a proportion which fell to $36.4 \%$ of the sample in the case of ethnic minority background respondents from England. Given that this has been one of the most stridently expressed claims for school history from many politicians and policy makers in recent years, it is interesting to note that many young people do not accept this premise.

Given that history is seen as playing an important role in promoting social cohesion and developing a sense of identity, as emphasised in the Ajegbo Report (DfES 2007), it is a concern that history seems to be failing in this role. Although there seems to be an obvious correlation between a subject like history and the promotion of identity, 'liberal' values and community 
cohesion, this is based upon little other than assumption. As Husbands, Kitson and Pendry (2003: 124) explain:

This argument is based on an (unproven) theory that understanding about different societies in the past might reduce fear of such differences and in turn, encourage greater toleration and respect for diversity today. It would be extremely valuable to have empirical research available which explores this theory further.

There is thus a need to explore more fully how (if at all) history impacts on young people and their sense of identity and orientation towards society more generally.

\section{Research Design}

Research Questions

The research conducted was a pilot, designed to gather some initial data and to test the data-collection methods in preparation for a subsequent larger-scale research project. The research focused on two areas, namely what was taught in the school history curriculum and why, and how pupils, especially those from minority ethnic backgrounds, responded to the curriculum. For the purposes of this paper the focus is on pupils and their responses to the curriculum. To address this the following questions were formulated: 
1) What do young people see as the purpose and value of history and to what extent is this related to their sense of belonging in society?

2) Which historical topics in the school curriculum do young people relate to most strongly and why, and which topics would they like to study?

\section{Research Methods}

One research aim was to comprehend how minority ethnic students identify with specific history curriculum content and to gain their ontological perspectives, their attitudes and feelings and sense of identity and connection to the history topics taught. Such a requirement calls for highly qualitative sensitive, interactive research. However, in order to capture initial large-scale data, a survey was conducted simultaneously with two classes in each school, four in total. Surveys enable standardized data gathering in efficient one-shot operations for statistical analysis (Cohen, Manion, Morrison, 2011). To explore further, it was decided to use focus group discussions with small groups of students, rather than individual interviews, as it was felt that students would be more comfortable discussing issues amongst their peers. Students were divided into ethnic majority and minority groups. This decision to hold discussions with students in separate minority and majority ethnic groups, as far as possible, was taken to ensure that students would not feel hindered in discussing issues of ethnicity, because as Hennick, Hutter and Bailey (2011: 150) argue, group homogeneity, i.e. for those with similar socio- 
demographic characteristics, is preferable as 'participants are more likely to share their views and experiences with others who are similar to themselves'.

Thus a mixed methods approach was adopted. It was hoped that the combination of a survey and focus group discussions would provide a degree of triangulation, allowing for greater plausibility and credibility to be established, and thereby providing internal validity. Internal validity is described by Cohen, Manion and Morrison $(2000,107)$ as demonstrating 'that the explanation of a particular event, issue or set of data ... can be sustained by the data.'

Sampling

Schools within an existing initial teacher training partnership in the South of England were approached to participate in the study. Due to the focus of the study, schools with a significant multi-ethnic population were asked to participate and two schools agreed; both were known to one of the researchers. Both schools are located close to each other in a large town in the South of England, but provide contrasting educational environments. School A has had a reputation as a 'challenging' school, but recent government inspection reports show the school is improving. The school serves an area of low socio-economic status, has a higher than average number of students with SEN and English as an additional language, and has a higher than average number of students from minority ethnic 
backgrounds. School B has traditionally had a strong reputation but a recent inspection has indicated that it needs to improve. The school population has fewer than average students with SEN or with English as an additional language; the majority of students tend to come from higher than average socio-economic backgrounds, and just under a quarter of students come from minority ethnic backgrounds.

Consent was obtained for each school's history department to participate in research over a six-month period from November 2012 to April 2013. The heads of history gave willingly of their time to submit information on their history curriculum topics at key stage 3 (for students aged 11-13/14), and in setting-up focus-groups.

Student sampling was therefore both opportunistic and purposive. The selection of classes to participate in the study was partly dictated by the head of history in each school and the availability of the researchers, whilst the selection of participants for focus groups was purposive. In total four classes (two in each school) participated (a total of 102 students). The two classes in School A were students aged 13-14, whilst the two classes in School B were students aged 12-13; of these students, 70 identified as 'white', 26 identified as coming from a minority ethnic background, with the rest declining to identify their ethnicity. From these classes seven small focus-groups were arranged, three of minority ethnic students, three of white British students, one was a mix of minority and majority ethnic students (total 42 students; 18 were from minority ethnic backgrounds and 24 were from white British backgrounds). Although it would also have 
been useful to analyse data by gender, permission from the university's research ethics committee was not granted.

\section{Data collection}

Altogether 102 surveys were completed and returned (54 from School A and 48 from School B). Following discussions with the schools it was agreed that the surveys would be administered by the class teacher. It was clear some teachers offered encouragement for the students in completing the survey, whilst others asked the students to complete the surveys in silence, which may account for some variability in some of the answers provided. The surveys listed all the topics taught to the students since they had been at the school (this information was given by the head of history early in the project, thus each survey was unique to the school) and students were asked, using a Likert-style range of responses (using a 1-4 scale of response with an option of 'I do not remember this topic' as a fifth response), to indicate which topics they enjoyed most, and to which topics they felt the strongest sense of personal connection. Students were also asked questions about their engagement with history outside of school, their overall enjoyment of history and whether they wished to study history at GCSE. Open questions were included on the questionnaires with students able to offer reasons, to comment, on their Likert-scale selections. Basic background information on students was also collected to provide variables to assist with the data analysis. 
However, from the completed survey forms, it was apparent that many students had difficulty understanding the meaning of 'personal connection' to some topics; that this would need further exploration via group discussions. It was also apparent that some topics listed on the survey form for School A were yet to be covered by students, so that not all questions could be answered at this stage but could be discussed later in the focus groups.

Pupils willing to participate in focus-groups were asked to indicate this on the survey forms. Focus-group discussions were decided upon, for, although they obtain less in-depth information than one-to-one interviews, they have the advantage of identifying a range of opinions, of collecting much detailed information quickly, plus they have a high emancipatory effect, as the different views within a group can open up new ways of seeing, encouraging discussion and debate, and thereby allowing participants to become more reflexive (Hennick et al, 2011). The researcher's focus-group guide was designed to explore the research questions and issues arising from the initial survey analysis. The data collection figure (see figure 1) outlines the data collected during the study. [insert Figure 1 around here] The project procedures adhered to permissions and conditions granted by the University of Reading's ethics committee. Informed consent was therefore obtained from each participating student and their parents, and 
agreement received to electronically record discussions; copies of the transcripts were made available to all participants for validation.

\section{Data Analysis}

Numerical information from survey questionnaires was put into SPSS (a software programme for statistical analysis) to produce frequency and cross-tabulation tables, while the survey's open questions were coded thematically. It was thus possible to count the frequency of particular coded types of response. As the focus was on how students from different ethnic backgrounds related to the history curriculum, responses could be analysed by school and by ethnic background.

Data from the focus group discussions were open coded individually by the researchers, and the results were then compared. There was strong overlap in the themes identified indicating a good level of inter-coder reliability, and therefore increasing the sense of internal validity.

\section{Findings}

The combination of survey and focus group discussions provided a good range of data to explore what these students saw as the purpose and value of history, and how strongly they related to the topics they had studied. The focus groups provided richer data as it enabled the researchers to probe a little deeper into students' views about the history they were 
taught. Thus in this section we will draw upon both types of data but will present more points raised from the focus groups.

We will start by presenting the findings in terms of responses relating to the perceived purpose and value of history. Next we will look at pupils' sense of identity and belonging. To do this we will explore both their enjoyment of history, followed by their sense of personal connection to the topics studied. Although these two elements of enjoyment and connection are linked, they are also distinctive, so will need to be disentangled. Finally we will examine what students said they would like to study, as this gives some indication regarding the limitations of the current curriculum taught in both schools in terms of personal connection.

i) History as a subject: purpose and value

When asked to discuss why history was studied in schools, students in schools A and B struggled to articulate clear reasons. This was evident in both the survey responses and focus group interviews. In the surveys from School A, 11 students made suggestions that the topics studied were important somehow, whilst a further nine simply said it was important to know things. Eight students said history helped you understand the world today, but another nine students either did not respond or admitted that they had no idea why they studied history. The majority of responses show that students did not understand the study of the past in terms of disciplinary or postmodern rationales, despite these being a central element within the national curriculum, nor did the students see history 
in terms of developing a sense of identity, either at a personal or collective level. Their responses tend to fit more closely into aspects of Barton and Levstik’s (2004) 'analytical' and 'exhibition' stances. Responses from students in School B were very similar: eight students said they had to study the topics because they were important, a further seven said it was just important to know things. Fourteen responses indicated that either they did not know, or they did not provide any response. Only three students said that history was studied to help understand the world today, whilst another three said history was studied to avoid mistakes of the past.

The focus groups provided an opportunity to explore further students' understanding of the purpose and value of history, but responses were still limited. White students in School A spoke about understanding the UK or modern society; they could see how things have changed and thus appreciate what they might otherwise take for granted (A/FGD.3\&4). Some students also identified how studying history helped them to develop particular skills, such as essay writing. The minority ethnic groups in School A felt history was about big political events; governments and kings (A/FGD.1). In School B some students felt the topics they studied were because they were 'big' or 'important', and a couple of students mentioned specific jobs where history might be useful (B/FGD2\&3). As with School A, history's purpose was mainly seen as teaching the 'important parts of history and events' and to inform how society has changed; democracy and women getting the vote were mentioned. The students from minority ethnic groups were clear that history lessons mainly taught British history 
and other places were discussed only if they linked into British history (B/FGD.1)

However in general most students, in both schools, were unable to offer any rationale for the study of specific topics, which drew upon notions of identity, disciplinary or postmodern rationales. Instead, students were more likely to identify reasons akin to Barton and Levstik's (2004) exhibition stance and some elements of their analytical stance, or simply explained they did them because they had no choice. This was clear both from the survey responses and focus groups.

ii) Sense of Belonging: enjoyment of history

Most students in both schools had had a positive experience of being taught history. This was true of students regardless of ethnic background, although in School A, students from white backgrounds, generally reported a slightly more positive experience than their peers from minority ethnic backgrounds, whilst there was no discernible difference between these groups in School B. It should be stressed, however, that numbers in both school samples are small and the survey findings reveal no significance statistical difference between students from white and minority ethnic backgrounds.

However the number of students wanting to study history for GCSE, did vary by ethnicity and school. At the time of the survey a number of students were undecided about whether to continue with history, but in 
School A the number willing to commit to history from minority ethnic backgrounds was much lower (see tables 1 and 2).

[insert Tables 1 and 2 here]

Focus group data revealed 32 of the 42 participants planned to take the subject at GCSE with ten declining, yet there was a clear difference between students from different ethnic backgrounds; seven out of 18 students from minority ethnic backgrounds did not want to study history at GCSE (two out of 11 in School A and five out of seven in School B), compared to three white students out of 24 (all in School B). The differences between the survey and focus group data may be a result of sampling and/or the timing of the data collection as the focus groups were conducted closer to the point at which students had had to make choices about their examination courses. However, these findings seem to indicate that students are sensitive to the topics they study. This in turn makes it important to understand the ways in which, if at all, pupils relate to the curriculum.

The focus group discussions revealed that, for School A, the most enjoyable, favoured topics were those focused on local history, the TransAtlantic Slave Trade (although this was yet to be studied the students, particularly from minority backgrounds, were looking forward to this), the Spanish Armada and the Industrial Revolution, while for School B similarly the enjoyable topics were an independent local history project, a topic on Oppression and Resistance (which covered the Trans-Atlantic Slave Trade 
and the persecution of the Jews), the Industrial Revolution and the World Wars. Reasons given for enjoyment in all focus-groups were a little vague and were typically: 'I know quite a bit already', 'I find it interesting', 'I enjoy it'. However one student from a minority ethnic background, finding the Trans-Atlantic Slave Trade enjoyable, clearly made a connection with the topic, declaring:

'it just fits in with the culture' (A/FGD.2 - S1)

The survey data supported these findings with the Spanish Armada being the most frequently cited enjoyable subject in School A while for School B, twenty-seven students found the independent local history project enjoyable as it enabled students to be free to focus on any aspect of history of the town in which they lived, and many chose to look at social, economic or cultural developments. There were a few key reasons for enjoying a topic. Many students simply found some topics intrinsically interesting. How topics were taught was also important, for example many students enjoyed topics where they were able to work in groups. Some students enjoyed working with resources related to particular topics. Additionally a number of students highlighted topics that allowed them specifically to understand the history of Britain. Interestingly two comments from survey responses in School A appeared to see British topics as understanding 'their' history:

because its (sic) about my native country (student 50d)

Because I got to know about my own country's past (student 54d) 
One of the students from a minority ethnic background said:

I also enjoyed it because I learnt about the English people (student 48d)

In this case, the use of the phrase 'the English people' seems to position the student possibly as an outsider.

Analysis of the surveys showed the most commonly cited reason for not enjoying a topic was simply that it was not interesting or was boring. Some students gave additional reasons. For many, the teaching approaches failed to engage them; students cited an over use of textbooks, having to copy from books and too much writing being requested. One student in School A did not enjoy the topics, because, as she said 'I am black'. This could indicate a possible dissatisfaction with the range of topics studied for being too 'white, Anglo-Saxon British'. In School B, where students studied topics on Islamic history, several white students disliked the topic:

because it is the history of a different country (student 2a)

because it has nothing to do with our country's history (student 40b)

This suggests unwillingness on behalf of some white students to engage with different narratives.

The focus group discussions provided additional evidence to support the points raised in the survey data. For instance, four students in School B felt the Islamic Empire topic was too hard to understand, they could not make sense of the history (B/FGD.3). Moreover, some students from minority ethnic backgrounds said they felt that they were taught a rather 
one-sided view of the past. For example one student complained about the negative portrayal of black people in the topic covering slavery:

like the Slavery, it says what happened to Black people but nothing really, like, good, like they need to do some stuff like what happened to them as well, like good things that happened to them (B/FGD.1 - S1)

This was a point supported by other students in this focus group, and interestingly was similar to a point raised in School A as well, where students from minority ethnic backgrounds stated that they were taught an overwhelmingly positive view of Britain, whereas their own perception was very different:

They changing like, bad things into good things like they needed to do slavery...no they didn't (said forcefully)...because they weren't treating us like, fairly. (A/FGD.2 - S6)

Students were also asked questions on the survey to assess their level of engagement with history outside of school to see whether this differed to their engagement with history in school, thus they were asked whether anyone in their family enjoyed history, whether they found out about history in their own time, visited historic sites, read historical books, watched historical TV programmes, and played historical games. Figures from School A show that students from majority and minority ethnic backgrounds displayed similar levels of interest, with students from white backgrounds displaying just slightly higher levels of interest - on the whole students were more likely to read stories, play games or watch TV 
programmes with an historical theme rather than visit sites or find out about history in their own time. This stands in contrast to levels of enjoyment with white students showing higher levels of engagement with history in school compared to outside. In contrast, students from minority ethnic backgrounds in School B, were far more likely than their white peers to visit historic sites, read historical stories, watch historical TV programmes and play games with an historical theme, yet white students were marginally more likely to enjoy history in school.

Overall, although there is a mixed picture, there was a clear sense that the majority of students found history an enjoyable subject for various reasons. However, the level of enjoyment was influenced by the specific nature of the topics studied and the way in which this intersected with a student's sense of self in some cases, which will be explored further in the section below.

iii) Sense of Belonging: Identity and Cohesion

Students were asked, in the focus groups, how they would describe their ethnic identity. Clearly identity is made up of several facets, of which ethnicity is one feature, but it was important to explore this aspect in the context of this study to ascertain whether students felt their ethnic identity was reflected in the history curriculum, and therefore whether they felt any connection to what they were being taught. Some students from minority ethnic backgrounds seemed unsure how best to describe their identity, especially coming from mixed race parentage, although 
some White British were also unsure whether they were English before British or vice-versa. When asked if learning history helped give them a sense of identity, few were able to give any affirmative responses, with only one White British student venturing that it did 'in a way, as like a country, but not like individually really...unless you can relate to it' (B/FGD.2)

It was clear that some students found 'personal connection' difficult to comprehend when completing the survey form. However, analysis of the survey data did highlight that many students felt some personal connection to the history topics, which were predominantly based around notions of connection to the locality/nation and family participation in events. In School A eight students said they felt a personal connection to the topic of the Spanish Armada (mainly because the British defeated a 'foreign' enemy), seven felt connected to a study of the local area during the Industrial Revolution. The topic on Britain 1750-1900 revealed higher levels of connection from minority ethnic students, which initially seemed surprising, especially as the brief explanations offered in the survey did not illuminate this any further. It was only during the focus group discussions that the reason for a sense of connection became apparent. A number of students explained how their grandparents had had to work in factories when they first settled in the area, and so the focus on factory conditions within the history topic (although from a different era) made them reflect on the experiences of their family. 
The survey responses from School B showed a strong sense of connection to an independent research project on the local town, cited by $50 \%$ of students. The topics on World War One and warfare in the twentieth century were the others to which students felt most closely connected (15 and 14 students respectively). Looking at the level of connection by ethnicity revealed some differences, but this varied by topics. For example students from white backgrounds were more likely to cite a connection to events that were 'British', whereas students from minority backgrounds said they felt more closely connected to topics such as the Trans-Atlantic slave trade. For example, one student from School B specifically mentioned their ethnicity in explaining a sense of connection to the topic Oppression and Resistance (which included a study of the Trans-Atlantic Slave Trade) stating, 'because I also have a dark colour' (student 15a).

In the focus group discussions the immediate response was that students found no connections to topics, but further exploration revealed they did. Several students mentioned their family connections, for example, family members involved in or living through the Second World War:

'the World War [topic], yeah, because my Grandads both fought in it' (B/FGD.2 - S1)

Others felt connections to local history, for instance: 'the project, last year, on (local town)...cos, I've lived here quite long' (B/FGD.3 - S4) 
Another student related to 'Tudor Times', because a primary school trip brought back memories and the same student related to the Industrial Revolution as 'my mum used to work in a factory' (A/FGD.3 - S4). Overall there appeared to be an association between topics which were enjoyable and those where students expressed a personal connection, i.e. the local town project in School B was the one most enjoyed and to which the students felt closely connected. The survey data supported this with 24 students citing this topic.

A sense of pride in Britain's achievements was evident only from white students, for example:

'When I was doing the Industrial Revolution it was sort of I was proud because it was going to turn into such a big Empire' (A/FDG.4 - S5)

'Yeah but if ... if none of this like, Revolution, like happened, like we wouldn't be the fourth richest country in the world like we are today... and so it is basically, thanks to the people who went through it that we're here, where we are today' (A/FDG.1 - S2)

White students on the whole felt events such as the Empire, Britain's involvement in the world wars and events like the defeat of the Spanish Armada were reasons to feel proud. Minority ethnic students, in contrast to their white British counterparts, did not refer to pride. They were clear it was important to learn about the history of Britain, as it was the country in which they lived, but they also recognized their own hybrid identities 
and were keen to learn about history relating to their own backgrounds, as this discussion indicates:

S1 Yeah, yeah. To learn about British history when we live in Britain is important, but, it would be like... it will be more...the lessons will be like much more interesting if we learnt about our backgrounds and like the places where we come from, because there's loads of different like, um, there's loads of people with like different ethnicities in our school, so I don't think it's like ...I think it's important but on the other hand I think it's like we should learn about the places where we came from, not just like, the same place all the time.

S2 Um, I think it...I think it's really important to learn about British history but ...but as well, at the same time, it's kind of unfair that we don't get to learn about our own backgrounds...because we're not um English... so.

I Okay

S3 Err, it's important to learn about British cultural history because we live in Britain, but then you have to learn about your own... like, country, like so, you still have like your culture and tradition and you remember what it's like... how like, your country was ever formed.

I Right, okay

S4 Um, yeah, I think we should learn about our different countries ...our own countries, like from where our parents came from or grandparents 
came from, because well...I've been to Pakistan a few times but I have never known like, anything about it... I know maybe who the President is and that's it, but what...I haven't learned about the history of it, so...if we learn about the history of it, like say there was an Industrial Revolution there as well and - or something like that - or, because, it hasn't got much better they're still cutting crops with hand and stuff like that ...but...yeah.

I Okay

S5 Um it's important to learn about British history because we're in Britain and...but I think it's all...I think we should also do, like, other people's backgrounds because we mostly just do British and it's not fair on other people. (A/FGD.3)

White students did seem to make a personal connection when they voiced disquiet over Britain's role in the Trans-Atlantic Slave Trade and revealed much empathy for their black counterparts in the classroom who, one said, 'must think about it' when learning the slavery topic (B/FGD.2 - S). Similarly in School A, white students made comments such as:

'We caused it ....it makes me feel a bit mean, I wasn't there, I still feel guilty' (A/FDG.3 - S4)

There was a strong sense from many of the students from minority ethnic backgrounds that the history curriculum did not include them. Students 
were asked whether they felt they studied too much British/white history and some spoke passionately of their feelings of marginalization:

'They [white students] know more about...their country, their life and everything because they...came from here...but we wouldn't know much about our home town or whatever because... we haven't been there' (A/FGD.3 - S4)

'I think if you talk about British history and British history and British history, they don't talk about like us...it's like there's no black people in the history, they're always talking about... what the white people did in history' (A/FGD.4 $-\mathrm{S} 6)$

Although many students felt little or no personal connection to the majority of topics taught, it was clear that where students felt a sense of connection there was a greater sense of engagement and enjoyment. However at the same time it was clear that for some students from minority ethnic backgrounds the absence of a personal connection did make some of them feel marginalized. It was, therefore, felt appropriate to explore what students would like to study, either to make the subject more enjoyable or to help students feel a stronger sense of connection to the past.

iv) New topics seen as desirable

Many students were able to talk about the limitations of what they studied, therefore what they would not like to do, and by implication what they would prefer to study. 
As part of the focus group discussions on history as a subject, some interesting themes emerged. For instance many students from minority ethnic backgrounds felt there was extensive repetition in the curriculum, when comparing what they had studied at primary school and what they were doing in secondary school.

'I think we do, do a bit too much because in primary school and in year seven we learnt about Tudors and Victorians and like the traditional things' (A/FGD.1 - S4)

'Sometimes we're just seeing stuff over and over again and it starts to get boring' (A/FGD.2 - S2)

This degree of repetition was not something mentioned by students from white backgrounds. There seems to be an emphasis on British history at both primary and secondary level, which serves to reinforce the white, Anglo-Saxon nature of the curriculum. Although students felt it was valuable to study British history, all focus groups, in schools A and B, felt it would be valuable to study history from other parts of the world. There were many comments that showed students wanted to study more cultural and social history, which seemed to imply a dissatisfaction with a curriculum that focused heavily on political events. In addition, there was a feeling that not only was the curriculum dominated by political history, it was also narrowly British history:

'I think it's important to learn about British history because we're in Britain...but I think...we should also do other people's backgrounds because 
we mostly do British and it's not fair on other people...English students could learn other backgrounds' (A/FGD.1 - S5)

'It's like there's no black people in the history, they're always talking about what the white people did in history - need British and other stuff (A/FGD.2 S4)

'It's important to learn about British cultural history because we live in Britain, but then you have to learn about your own...country, like so you will still have like your culture and tradition' (A/FGD.1 - S?)

'We should study other countries as well...if we just study what we've done then it doesn't really give you an overall understanding...I think it's good to do both, yeah, learn about British and about other countries' (A/FGD.3 - S5).

'It would be nice to learn about different places in the world with different backgrounds' (B/FG1 - S4)

'we still should learn British...as we live in England ...but...better if we learnt about India, China, Japan and America' (B/FGD.1 - S3)

'Because it would be nice to learn about different countries and not just Britain. Cos in primary school, you do Britain, and basically all we're doing is the same thing over again just in more detail' (B/FGD.1 - S4)

The danger with this, as this particular student explained, was:

'They (white students) think everything's white, think everyone's white' 
Several of the students from minority ethnic backgrounds expressed a concern that white students would lack an understanding of others from non-white backgrounds, which would be detrimental to different groups getting along. One student explained about the problem of stereotyping:

'Because, each time... like sometimes in class they will say when you say Africa, what's the first thing that comes into your head, and I just think 'poor' but...I think in my primary school we did like an 'around the world' week, and then it showed that not all of Africa's poor, so... and I didn't even know that, cos, like on TV they were saying help Africa and the charity and stuff, and when you realize that not all of it's poor, you're like 'oh'...' (B/FGD.1 - S4)

All students, both those from majority and minority ethnic backgrounds, appeared keen for more World history. Indeed in focus-group 3 in School B, two pupils originating from Spain and Hong Kong declared that they would like to study their respective countries. Similarly in School A more world history was desirable, with China, Africa and Caribbean histories being mentioned. Other new topics thought desirable in both schools were named as crime and punishment, history of medicine, history of music and history of clothing. Music and medicine were mentioned by several students. These ideas suggest a desire to study topics with a social or cultural perspective.

For the ethnic minority groups, family history appeared to be something they would like to study for:

'it would be quite interesting to know about the family' (B/FGD.1 - S1) 
This was seen as having several advantages. It would allow the students to understand more about their own backgrounds and where their families had come from. One student, for example, was aware that his family had suffered during the Partition of India in 1947 but knew little about the events, whilst another student from Pakistan said she could say who was president of the country but knew little else about her family's country. A focus on family history would also allow these students the opportunity to understand better the connection between the history of Britain and the countries where their families had originated, thereby helping to make connections between topics and placing events into a broader context. In this way the study of micro-histories could throw light on bigger issues and vice versa. It also offers the opportunity for all students to appreciate the diversity of their own and each other's backgrounds, as it is possible that the families of white students may have surprisingly complex histories. As such the suggestion of studying personal, family history offers the possibility of engaging students both in terms of enjoyment and personal connection.

\section{Discussion}

The findings from this small-scale study suggest that students have little real understanding why they study history, either from the perspective of a collective memory as desired by many politicians, or from a disciplinary or postmodern perspective as advocated by many history educationalists. In many ways this is unsurprising as it replicates findings from previous studies. For example VanSledright (1997) and Haydn and Harris (2010) 
found that students' conceptions of the purpose of history were often simply related to employment prospects, such as being a history teacher or an archaeologist. However, as previous studies have shown (Harris and Haydn 2006) students tend to enjoy studying history for a variety of reasons; these are often related to the teacher (and whether pupils liked them), how they are taught and whether students find the topic intrinsically interesting. There is however a sense that white students are marginally more likely to enjoy the subject in these schools, which is reflected in the numbers indicating they wish to take the subject at GCSE (and which also follows the wider national trend). The reasons for this are not immediately obvious, but it is clear from some of the data collected that students from minority ethnic backgrounds do enjoy the subject, but not necessarily what is taught in school.

There have been few studies that actually examine what is taught in schools and whether such topics that are chosen are seen as appropriate by students. The debates about content tend to be conducted within a discourse focused on developing a sense of national identity (Harris 2013, Osler 2009). Yet this study shows that students do not see history as a conscious element in the development of their sense of identity or of a collective identity. To an extent this is understandable as most people would be unaware of the explicit way in which a range of factors shape their identity. There are, however, indications that history implicitly feeds into a student's sense of who they are. White students were more likely to express pride in past events relating to 'British' achievements in the past, 
particularly where Britain had won victories over other nations or had played a perceived positive role in major world events, whereas students from minority ethnic backgrounds were unlikely to express any pride for such achievements, although they felt it was important to understand the country in which they live. What is taught in these schools is essentially Anglo-centric. There are topics which could link into wider aspects of history, yet the overwhelming feeling from the students is that the curriculum is too narrow. Consequently students from minority ethnic backgrounds do not see themselves in the curriculum. For black students the only time they will encounter black people in the past will be in the context of slavery, whilst students from an Asian heritage are unlikely to be taught anything that includes history that encompasses their background.

\section{Conclusions}

Clearly this was a small scale study, and it is dangerous to make large claims based on such studies, but it can be argued that the curriculum, which has a disciplinary approach at its heart, combined with a content that focuses on a narrow national story is proving inadequate in these settings. It does not seem to enable students to see how the past is constructed, represented and used, nor does it help them develop a sense of a personal or collective identity.

The students seem to want more than the current curriculum is offering. There is a desire amongst the students in this study, from majority and 
minority ethnic backgrounds to be taught a more diverse past, both in terms of geographical spread, types of history and historical perspectives. For some students there is also a desire to use history to understand their own personal backgrounds. There should be ways in which students could be helped to connect more with history and appreciate its value to their lives. For example it was clear that local history was popular with students and this could easily be incorporated more widely into school history, using a disciplinary or postmodern approach. In addition, this could be combined with a transnational theme such as migration, which would allow students to examine population movement in the locality over time and which would allow students to examine the movement of their own families. This could have the benefit of developing a more inclusive sense of a collective local identity.

This may not require a radical overhaul of the curriculum but it may need a shift in how teachers interpret the curriculum. It does seem that more careful thought needs to be given to the needs of students, both in terms of understanding the value of history and choosing historical content. These findings also suggest that it would be valuable to examine further what history is taught in schools and the ways in which students connect to the past.

${ }^{1}$ Michael Gove is the Secretary of State for Education. He is a Conservative politician, and part of the Conservative-Liberal Democrat coalition government. 
${ }^{2}$ At the time of this speech, Gordon Brown was Chancellor of the Exchequer in the New Labour government. Subsequently he held office as Prime Minister of the UK.

${ }^{3}$ GCSE is the General Certificate of Secondary Education and is the main examination for 16 year olds in England, Wales and Northern Ireland. The exam is graded $A^{*}-G$, with grades $\mathrm{A}^{*}$-C being considered 'good' passes, and used as a measure to judge school effectiveness.

${ }^{4}$ Advanced level is the main examination for 18 year olds in England, Wales and Northern Ireland

\section{References}

Ahonen, S. (2005) Historical Consciousness: a viable paradigm for history education? Journal of Curriculum Studies, 37 (6), 697-707

Barton, K. (2012) School history as a resource for constructing identities: implications of research from the United States, Northern Ireland, and New Zealand. In M. Carretero, M. Asensio and M. Rodriguez-Moneo (eds), History Education and the Construction of National Identities (Charlotte, NC: Information Age Publishing), 93-107.

Barton, K. and Levstik, L. (2004) Teaching History for the Common Good (Mahwah, NJ: Lawrence Erlbaum Associates Publishers).

Berger, S. (2012) De-nationalizing history teaching and nationalizing it differently! Some reflections on how to defuse the negative potential of national(ist) history teaching. In M. Carretero, M. Asensio and M. 
Rodriguez-Moneo (eds), History Education and the Construction of National Identities (Charlotte, NC: Information Age Publishing), 33-47.

Brown, G. (2006) The future of Britishness. Keynote address given to the Fabian Society Conference on Britishness. Available online at:

www.fabians.org.uk/events/speeches/the-future-of-britishness, accessed March 27, 2013.

Cohen, L., Manion, L., and Morrison, K. (2000) Research Methods in Education, 5th edn., (Abingdon: Routledge).

Cohen, L., Manion, L., and Morrison, K. (2011) Research Methods in Education, 7th edn., (Abingdon: Routledge).

DfES (2006) Ethnicity and education: The evidence on minority ethnic pupils aged 516 (London: DfES).

DfES (2007) Diversity and Citizenship Curriculum Review (London: DfES).

Epstein, T. (2009) Interpreting national history (New York: Routledge).

Gay, G. (2004) Curriculum theory and multicultural education. In J. A. Banks and C. A. McGee Banks (eds), Handbook of research on multicultural education (San Francisco, CA: Jossey-Bass), 30-49.

Gibb, N. (2011) History: GCSE House of Commons Parliamentary Debate 19 July 2011 c909/910W. Available online at: http://www.publications.parliament.uk/pa/cm201011/cmhansrd/cm110719/t ext/110719w0005.htm, accessed July 28, 2013. 
Gove, M. (2010) Speech to the Conservative Party conference in Birmingham. Available online at www.epolitix.com/latestnews/articledetail/newsarticle/speech-in-full-michael-gove/, accessed October 20, 2012. Green, A. Preston, J. and Sabates, R. (2003) Education, Equality and Social Cohesion: A distributional approach, Compare: A Journal of Comparative and International Education, 33:4, 453-470

Grever, M. (2012) Dilemmas of common and plural history: reflections on history education and heritage in a globalizing world. In M. Carretero, M. Asensio and M. Rodriguez-Moneo (eds), History Education and the Construction of National Identities (Charlotte, NC: Information Age Publishing), 75-91.

Grever, M., Haydn, T. and Ribbens, K. (2006) Identity and school history: The perspectives of young people from the Netherlands and England. Paper presented at European Educational Research Association (University of Geneva, Switzerland).

Hansen, J. (2012) De-nationalize history and what have we done? Ontology, essentialism, and the search for a cosmopolitan alternative. In M. Carretero, M. Asensio and M. Rodriguez-Moneo (eds), History Education and the Construction of National Identities (Charlotte, NC: Information Age Publishing), 17-31.

Harris, R. (2013) The place of diversity within history and the challenge of policy and curriculum. Oxford Review of Education, 39 (3), 400-419. 
Harris, R. and Haydn, T. (2006) Pupils' enjoyment of history: what lessons can teachers learn from their pupils? Curriculum Journal, 17 (4), 315 - 333.

Hawkey, K. and Prior, J. (2011) History, memory cultures and meaning in the classroom. Journal of Curriculum Studies, 43 (2), 231-247.

Haydn, T. and Harris, R. (2010) Pupil perspectives on the purposes and benefits of studying history in high school: a view from the UK. Journal of Curriculum Studies, 42 (2), 241 - 261.

Henninck, M., Hutter, I., and Bailey, A. (2011) Qualitative Research Methods, (London: Sage Publications).

Hirsch, E. D. (1987) Cultural Literacy: What every American needs to know. (Boston: Houghton Mifflin).

Husbands, C., Kitson, A. and Pendry, A. (2003) Understanding history teaching (Maidenhead: Open University Press).

Lee, P. (1992) History in schools: aims, purposes and approaches. A reply to John White. In P. Lee, J. Slater, P. Walsh and J. White, The Aims of School History: The National Curriculum and Beyond (London: Tufnell Press), 20-34.

Marwick, A. (1989) The Nature of History, $3^{\text {rd }}$ edn. (Basingstoke: MacMillan)

McCrum, E. (2013) Diverging from the dominant discourse - some implications of conflicting subject understandings in the education of teachers. Teacher Development, 17 (4), 465-478. 
Nieto, S. (2004) Critical Multicultural Education and Students' Perspectives.

In G. Ladson-Billings and D. Gillborn (eds), The RoutledgeFalmer Reader in Multicultural Education (London: RoutledgeFalmer), 179-200.

Osler, A. (2009) Patriotism, multiculturalism and belonging: political discourse and the teaching of history. Educational Review, 61 (1), 85-100.

Seixas, P. (2000) Schweigen! die Kinder! Or does postmodern history have a place in the schools? In P. Stearns, P. Seixas \& S. Wineburg (eds.), Knowing, Teaching and Learning History (New York, NY: New York University Press), 1937.

Seixas, P. (2004) Theorizing Historical Consciousness (Toronto: University of Toronto Press).

Seixas, P. (2007) Who needs a canon? In M. Grever \& S. Stuurman (eds.). Beyond the canon: history for the twenty-first century (Basingstoke: Palgrave Macmillan), 19-30.

Tajfel, H. and Turner, J. (1979) An integrative theory of intergroup conflict. In W. G. Austin \& S. Worchel (eds.), The social psychology of intergroup relations (Monteray, CA: Brooks/Cole), 33-48.

Taylor, T. and Guyver R. (2011) History wars and the classroom: global perspectives (Charlotte, NC: Information Age Publishing).

Traille, E.K.A. (2006) School history and perspectives on the past: a study of students of African Caribbean descent and their mothers. Unpublished PhD (Institute of Education, University of London). 
VanSledright, B. A. (1997) And Santayana lives on: students' views on the purposes for studying American history. Journal of Curriculum Studies, 29 (5), 529-557. 